\title{
Correlated response in longevity from direct selection for production in the South African Jersey breed
}

\author{
J. du Toit ${ }^{1,2 \#}$, J.B. van Wyk ${ }^{2} \&$ A. Maiwashe ${ }^{3}$ \\ ${ }^{1}$ Agricultural Research Council, Animal Production Institute, Private Bag X5013, Stellenbosch, 7599, South Africa \\ ${ }^{2}$ Department of Animal, Wildlife and Grassland Sciences, University of the Free State, P. O. Box 339, Bloemfontein, \\ 9300, South Africa \\ ${ }^{3}$ Agricultural Research Council, Animal Production Institute, Private Bag X2, Irene, 0062, South Africa
}

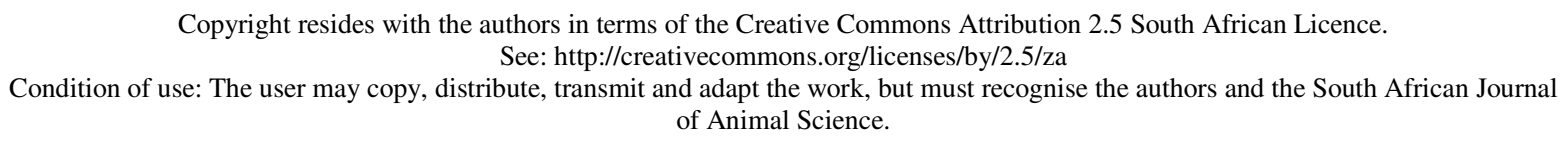

\begin{abstract}
The length of productive life is of major economic importance in dairy cattle production. Simple breeding objectives such as selection for increased production in dairy cattle have led to a significant decline in fitness traits. The objective of the current study was to investigate whether direct selection for production resulted in an undesirable genetic response in longevity in the South African Jersey breed. Longevity was defined as survival in the first three lactations from first calving to culling or death, adjusted for the effect of milk yield. An observation for survival per lactation was denoted by 1 (survived) or 0 (culled) otherwise. Performance and pedigree records on purebred South African Jersey cows that participated in the National Milk Recording and Improvement Scheme were considered. A multiple-trait linear animal model was used to estimate breeding values. A complete (co)variance structure for the additive genetic and residual effects for the three traits were used. Heritabilities used in the current study were 0.034, 0.022 and 0.026 for the 1st, 2nd and 3rd lactations, respectively. Reliabilities were approximated using the effective number of daughters. The estimated breeding values for sires ranged from 79 to 114 . The rate of genetic progress per year for the period 1985 to 2002 was statistically non-significant $(b=0.02 \pm 0.05$ per year). Results from the current study indicate that direct selection for production did not result in an undesirable correlated genetic response in longevity.
\end{abstract}

Keywords: Productive herd life, breeding values, genetic analysis

${ }^{\#}$ Corresponding author: dtoitj@arc.agric.za

\section{Introduction}

Longevity or herd life is of major economic importance in dairy cattle production (Boettcher et al., 1999a; Settar \& Weller, 1999). Longevity can be measured in a variety of ways, and genetic evaluations are not standardized across countries. However, its heritability is low, and herd life is expressed at a later age than traits used in the current South African Jersey selection programme.

Increased longevity affects overall profitability of milk production by reducing replacement costs and increasing the proportion of mature, high-producing cows in the herd. It also enables a greater selection response, because fewer cows have to be replaced, and therefore higher selection intensity of cows is possible (Vukasinovic et al., 2001). Selection for herd life is hampered by the time required for cows to have complete records. For maximum genetic progress, genetic merit of cows must be evaluated based on information that is available early in life. It therefore follows that genetic evaluation for herd life must be able to utilize incomplete herd life information on cows that are still in the herd when selection decisions are made (Jairath et al., 1998).

As a result, most national genetic evaluation programmes for dairy cattle include breeding values for longevity (Miglior et al., 2005; Forabosco et al., 2008). Different definitions for longevity have been considered in dairy cattle in several countries, leading to different models being implemented in national genetic evaluation for longevity (Sölkner \& Ducrocq, 1999; Veerkamp et al., 2001; Caraviello et al., 2004). 
These definitions are based on the number of parities or the actual length of herd life (Vollema \& Groen, 1996). Furthermore, genetic differences for milk yield will have a major effect on direct measures of survival, because low milk yield is a major cause of cow culling (Settar \& Weller, 1999). Many studies have proposed analysing functional herd life, which is generally computed as longevity adjusted for milk yield (Jairath et al., 1998; Settar \& Weller, 1999). This trait is independent of production, and reflects the fertility, health and overall fitness of the cow. In the present study functional herd life was defined as survival in the first three lactations with survival in each lactation considered as genetically correlated traits. Du Toit et al. (2009) found genetic correlations ranging from 0.68 to 0.99 between survival adjusted for production within each of the first three lactations. Jairath \& Dekkers (1995) reported genetic correlations among survival in the first three lactations. These values were only moderately high $(0.60$ to 0.75$)$, indicating that survival was a different genetic trait in each lactation. Boettcher et al. (1999) reported estimates that were higher $(0.84$ to 0.91). To accommodate these differences, the Canadian genetic evaluations models survival as different traits in the first three lactations, assigning cows to different contemporary groups for each subsequent calving.

The objective of the current study was to investigate whether direct selection for production resulted in an undesirable genetic response in functional longevity in the South African Jersey breed.

\section{Materials and Methods}

Performance and pedigree records of South African purebred Jersey cows that participated in the National Milk Recording and Improvement Scheme were obtained from the South African national livestock database, commonly known as the Integrated Registration and Genetic Information System (INTERGIS). The original data (before editing) included production records from 245134 Jersey cows from 2004 herds. These cows were progeny of 5364 sires and 124868 cows and were born between 1968 and 2005.

Observations for functional herd life were derived as follows: survival in a given lactation was determined based on the presence or absence of a subsequent lactation. Survival was treated as a binary trait and coded 1 if the cow survived and 0 if the cow was culled or if the number of days between the current calving date and extraction date exceeded 581. Records from cows in which the number of days between the current calving date and data extraction date were fewer than 581 were considered records in progress and were excluded from the analysis. The value 581 was calculated as mean calving interval plus 3 standard deviations (mean \pm SD values) to ensure each cow had enough opportunity to calve if it was still in the herd (Du Toit et al., 2009). The criteria used to determine survival are explained in Table 1.

Table 1 Criteria used to derive survival observations ${ }^{1}$

\begin{tabular}{llcl}
\hline & \multicolumn{3}{c}{ Survival in lactation } \\
\cline { 2 - 4 } Item & 1 & 2 & 3 \\
\hline Survived lactation 3 & 1 & 1 & 1 \\
Culled before lactation 3 & 1 & 1 & 0 \\
Culled before lactation 2 & 1 & 0 & - \\
Survived lactation 1 & 1 & - & -
\end{tabular}

${ }^{1}$ Survival is coded as 1 if a cow survived and 0 otherwise. The symbol "-" indicates that survival could not be determined (i.e. records in progress). Survival was determined as follows: for lactation $n$; survival $=1$ if there was lactation $n+1$, and survival $=0$ if there was no lactation $n+1$ and the number of days between current calving date and data extraction date exceeds 581. Survival is undefined (-) if the number of days between current calving date and extraction date is fewer than 581 .

The editing criteria employed in the official national evaluation for production traits for the Jersey breed were used. Specifically, the following records were excluded from the analysis: 1) test-day milk yield $<1 \mathrm{~kg}$ or $>70 \mathrm{~kg}$, fat percentage $<2 \%$ or $>9 \%$, and protein percentage $<2 \%$ or $>6 \% ; 2$ ) the interval between calving and first test day exceeding 75 days; 3 ) at least one interval between test dates exceeding 100 days; 
and 4) records with more than one test date interval between 60 and 100 days. Furthermore, 1) first lactation records terminated before 01 January 1989 were excluded because there were only a few cows with test-day records prior to 1989 ; 2) records with incorrect herd code and records outside specified age range were excluded; the allowable age ranges were as follows: 17 to 40, 29 to 53, and 41 to 67 months for first, second, and third parity, respectively; and 3) records with unknown registration status were excluded. A summary of the records excluded because of specific criteria is provided in Table 2. Most of the records were deleted mainly owing to first lactations being terminated before 01 January $1989(15.1 \%)$, followed by records with yield equals 0 (3.6\%) and records out of age range for the first three parities (2.2\%).

Table 2 Numbers and proportions of test-day records excluded from the analyses for functional herd life in the SA Jersey breed

\begin{tabular}{lrr}
\hline Type of edit & $\begin{array}{r}\text { Number of } \\
\text { records } \\
\text { removed }\end{array}$ & $\begin{array}{c}\% \text { of } \\
\text { records } \\
\text { removed }\end{array}$ \\
\hline First lactation records terminated before 01 Jan 1989 & 615323 & 15.12 \\
Records with incorrect herd code & 637 & 0.02 \\
Records with yield equals 0 & 148454 & 3.65 \\
Records out of age range & 87580 & 2.15 \\
Records with unknown status & 416 & 0.01 \\
Records outside yield range & 33 & 0.01 \\
Records with first test date $>75$ days & 21853 & 0.54 \\
Records with intervals between test dates $>100$ days prior to 305 days of lactation & 7173 & 0.18 \\
Records with more than one interval between 60 and 100 days & 17894 & 0.44 \\
\hline
\end{tabular}

After editing, the data comprised 125896,84133 and 52833 cows with 1st, 2nd and 3rd lactation longevity observations. These cows were daughters of 3736 sires. A total of 963 herds were represented in the data. The minimum and maximum number of daughters per sire was 1 and 3899 , respectively, with a mean of 30 daughters per sire. Summary statistics of the edited data are provided in Table 3.

Table 3 Summary statistics of the edited data

\begin{tabular}{lccccc}
\hline Item & $\mathrm{N}$ & Mean & $\begin{array}{r}\text { Standard } \\
\text { deviation }\end{array}$ & Minimum & Maximum \\
\hline $\begin{array}{l}\text { Age at first calving (months) } \\
\begin{array}{l}\text { Fat yield in first lactation (standard } \\
\text { deviation) }\end{array}\end{array}$ & 125896 & 26.31 & 3.96 & 17.00 & 40.00 \\
$\begin{array}{l}\text { Protein yield in first lactation } \\
\text { (standard deviation) }\end{array}$ & 125896 & 0.50 & 1.02 & -5.00 & 5.00 \\
Survival in lactation 1 & 125896 & 0.50 & 1.02 & -5.00 & 5.00 \\
Survival in lactation 2 & 125896 & 0.75 & 0.43 & 0.00 & 1.00 \\
Survival in lactation 3 & 84133 & 0.74 & 0.44 & 0.00 & 1.00 \\
& 52833 & 0.71 & 0.45 & 0.00 & 1.00 \\
\hline
\end{tabular}

A three-trait mixed linear animal model was used to estimate breeding values for survival. A matrix representation of the models for survival in each of the three lactations is as follows:

$$
\mathbf{y}=\mathbf{X \beta}+\mathrm{Za}+\mathrm{ZQg}+\mathbf{e}
$$


where $\mathbf{y}$ is a vector of observations, $\boldsymbol{\beta}$ is a vector of fixed effects, $\mathbf{a}$ is a vector of random additive genetic effects, $\mathbf{g}$ is a vector of genetic group effects, and $\mathbf{e}$ is a vector of random residuals. $\mathbf{X}$ and $\mathbf{Z}$ are incidence matrices relating fixed and random effects respectively to observations; $\mathbf{Q}$ is an incidence matrix that relates animals to genetic groups. The following distributional assumptions were made about the random effects: $\mathbf{a} \sim$ $\mathrm{N}\left(\mathbf{0}, \mathbf{A} \sigma_{\mathrm{a}}^{2}\right)$ and $\mathbf{e} \sim \mathrm{N}\left(\mathbf{0}, \mathbf{R} \sigma_{\mathrm{e}}^{2}\right)$. The $\sigma_{\mathrm{a}}^{2}$ and $\sigma_{\mathrm{e}}^{2}$ are the animal additive genetic and residual variances, respectively. The $\mathbf{A}$ is the Wright's numerator relationship matrix and $\mathbf{R}$ is a residual matrix.

The fixed effects considered in the model were herd $\mathrm{x}$ year; registry status $\mathrm{x}$ herd size change $\mathrm{x}$ season (RHS); age at first calving (linear and quadratic regression); linear regression on normalized deviation of 305-day protein yield in lactation 1 within RHS; linear, quadratic and cubic regressions on normalized deviation of 305-day protein and fat yields. Fixed effects were defined as follows: Registration status was defined in two classes: cows in herds with registered cows; and cows in herds with non-registered cows. Three classes for change in herd size were defined based on the percentage of change from one year to the next (decreasing $=$ for a decrease in herd size of $<-5 \%$; nearly unchanged $=$ no appreciable change $\geq-5 \%$ to $\leq 10 \%$; and increasing $=$ for increasing in herd size of $>10 \%$ ). Similar to Mostert et al. (2004), two seasons of calving were defined as Winter (season 1, from April to September) versus Summer (season 2, from October to March).The first lactation protein and fat yields were used because the genetic correlation between first lactation yield and yield in later lactations is high. Furthermore, low yield in the terminal lactation could have been caused by a health problem, which is what functional herd life attempts to measure (Short \& Lawlor, 1992).

A pedigree file used in the current study to account for relationships among animals included all cows with observations and their ancestors $(n=456355)$ and genetic groups $(n=69)$. A genetic group was defined as a concatenation of country of origin, year of birth, and selection path (e.g. sire of sire, sire of dam, dam of sire and dam of dam). Table 4 shows the levels of the fixed and random effects considered in the current study.

Table 4 Levels of fixed and random effects included in the model

\begin{tabular}{|c|c|c|c|}
\hline \multirow{2}{*}{ Item } & \multicolumn{3}{|c|}{ Number of levels } \\
\hline & Lactation 1 & Lactation 2 & Lactation 3 \\
\hline \multicolumn{4}{|l|}{ Fixed effects } \\
\hline herd xyear & 4991 & 3760 & 2726 \\
\hline registry status $\times$ herd size change $\times$ season $($ RHS) & 16 & 17 & 17 \\
\hline 305-day protein yield in lactation 1 within RHS & 143 & 125 & 122 \\
\hline age at first calving & 1 & 1 & 1 \\
\hline fat (linear) & 1 & 1 & 1 \\
\hline fat (quadratic) & 1 & 1 & 1 \\
\hline fat (cubic) & 1 & 1 & 1 \\
\hline protein (linear) & 1 & 1 & 1 \\
\hline protein (quadratic) & 1 & 1 & 1 \\
\hline protein (cubic) & 1 & 1 & 1 \\
\hline \multicolumn{4}{|l|}{ Random effects } \\
\hline animal & 456424 & 456424 & 456424 \\
\hline
\end{tabular}

The (co)variance components used in the current study were derived from estimates obtained from a multiple-trait sire model by Du Toit et al. (2009). The (co)variance components are provided in Table 5. The (co)variance components were derived as follows: 
(1) Additive genetic variance for a given lactation using $\sigma_{a_{\mathrm{i}}}^{2}=4 \sigma_{\mathrm{s}_{\mathrm{i}}}^{2}$

(2) Additive genetic (co)variance between two lactations using $\sigma_{a_{i}, a_{j}}=4 \sigma_{s_{i}, s_{j}}$ for $i \neq j$

(3) Residual variance using $\sigma_{e_{i}}^{2}=4 \sigma_{s_{i}}^{2}\left(1-h_{i}^{2}\right) / h_{i}^{2}$

(4) Residual (co)variance between two lactations using $\sigma_{e_{i}, e_{i}}=-3 \sigma_{s_{i}, s_{i}}+\sigma_{E_{i}, E_{i}}$ for $\mathrm{i} \neq \mathrm{j}$, where $\mathrm{E}_{\mathrm{i}}$ is the residual from a sire model.

Table $5\left(\right.$ Co)variance components $\left(\times 10^{-3}\right)$ and heritability estimates used in genetic evaluation of longevity in the South African Jersey breed

\begin{tabular}{lccc}
\hline \multirow{2}{*}{ Item } & \multicolumn{3}{c}{ Lactation } \\
\cline { 2 - 4 } & 1 & 2 & 3 \\
\hline \multirow{2}{*}{ Additive genetic (co)variances } & 5.12 & & \\
& & 4.29 & 3.31 \\
& & 3.69 & 4.98 \\
& & & \\
Residual (co)variances & 146.25 & -0.69 & -5.32 \\
& & 164.89 & -2.79 \\
& & & 176.87 \\
$\mathrm{~h}^{2}$ & & & 0.026 \\
\hline
\end{tabular}

Estimated breeding values (EBVs) were obtained using PEST (Groeneveld et al., 1994). Estimates of breeding values for lactations 1, 2 and 3 were obtained from solving the mixed model equations. The three EBVs were assumed to be equally important and combined into a single breeding value as $\mathrm{EBV}_{\mathrm{L}}=\left(\mathrm{EBV}_{1}+\mathrm{EBV}_{2}+\mathrm{EBV}_{3}\right) / 3$. Therefore, the EBV for longevity in the current study is an indication of the ability of a sire's daughters to survive the first three lactations. This approach is similar to that used in the Canadian genetic evaluation in Holsteins (Boettcher et al., 1999b).

The scale or unit of the breeding values is unknown when using a linear sire model. To present the breeding values on a desired scale, the breeding values were standardized by using the mean and standard deviation of the base group. The base group was defined as proven sires born between the years 1990 and 2000 inclusive. The standardized breeding values were then expressed as relative breeding values by using the mean of 100 and standard deviation of 5, similar to the procedure used by Van der Linde et al. (2007).

Accuracies were computed following the method of Liu et al. (2004):

$$
\mathrm{R}^{2}=\frac{\mathrm{n}_{\mathrm{ei}}}{\left(\mathrm{n}_{\mathrm{ei}}+\mathrm{k}\right)}
$$

where $\mathrm{k}=\frac{\left(4-\mathrm{h}^{2}\right)}{\mathrm{h}^{2}}$ and $\mathrm{n}_{\mathrm{ei}}$ is the effective number of daughters for sire $i$. The effective number of daughters was computed as follows (Fikse \& Banos, 2000):

$$
\mathrm{n}_{\mathrm{ei}}=\mathrm{n}_{\mathrm{ti}}-\sum_{\mathrm{j}} \frac{\mathrm{n}_{\mathrm{ij}}}{\mathrm{n}_{\mathrm{j}}}
$$


where $\mathrm{n}_{\mathrm{ti}}$ is the total number of daughters of sire $i, \mathrm{n}_{\mathrm{ij}}$ is the number of daughters of sire $i$ in contemporary group $j, \mathrm{n}_{\mathrm{j}}$ is the size of contemporary group $j$, and summation is over all the number of contemporary groups that sire $i$ has daughters. This method is considered standard in dairy cattle genetic evaluation systems.

The criteria for official publication of breeding values for proven sires were that sires were required to have at least one daughter with an observation for herd life; and a minimum of 20 daughters in 10 herds with milk production records. A total of 559 sires met the criteria for publication.

Genetic trend was obtained by regressing the mean breeding value on year of birth of sires that met the criteria for publication.

\section{Results and Discussion}

The distribution of the EBVs for the proven sires is shown in Figure 1. The mean and standard deviation of the breeding values of these sires were 99 and 5, respectively. These values were similar to the assumed mean and standard deviation of 100 and 5, respectively. The range of the breeding values was 79 to 114.

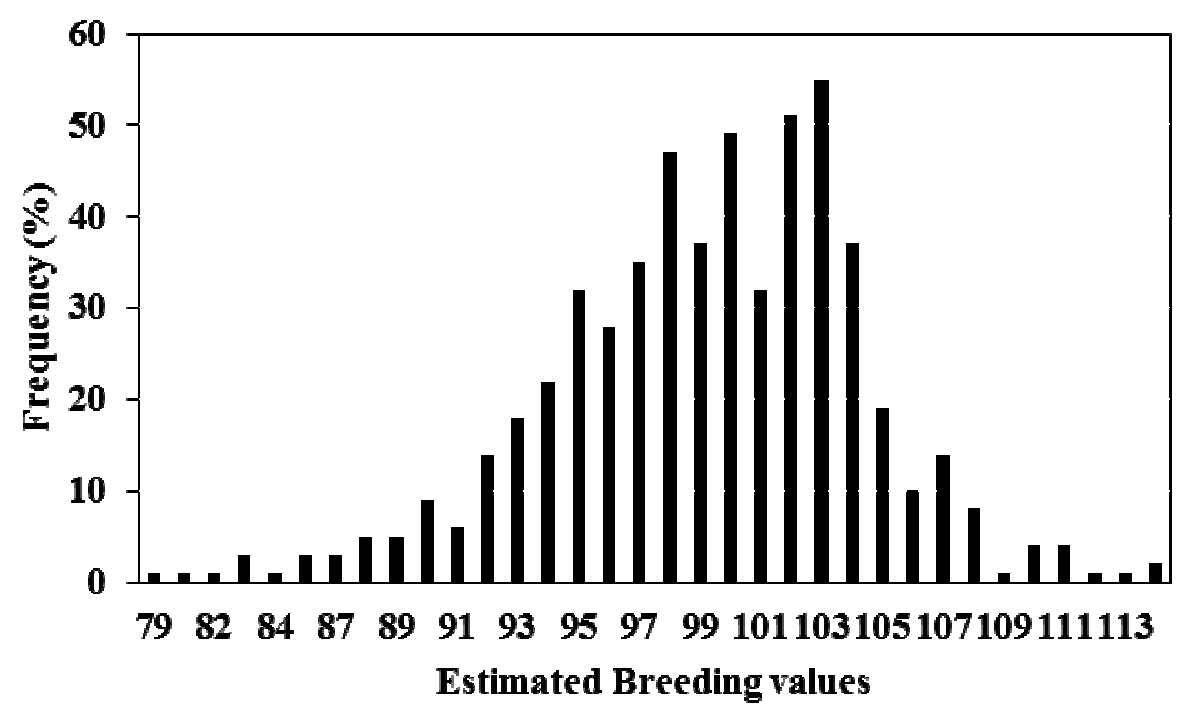

Figure 1 Distribution of estimated breeding values for functional longevity for all proven sires $(\mathrm{N}=559)$.

Different expressions of nationally predicted sire breeding values for longevity exist in other countries. Canadian bull proofs on Holsteins for combined herd life are expressed in terms of relative breeding values (RBVs) using a scale with an average of 100 and a range of 85 (undesired) to 115 (desired) to include 99\% of all proven sires (Van Doormaal, 2010). Boettcher et al. (1999b) expressed the results of bulls for combined herd life as expected transmitting abilities (ETA) for the number of lactations that daughters are expected to survive, after adjustment for production, standardized to a base of three lactations. The EBV ranged from 2.22 to 3.40 with a standard deviation of 0.15. Using a similar procedure, Jairath et al. (1998) reported a standard deviation of ETA of 0.156 lactations, and the range was from 2.31 to 3.43 lactations. In the national genetic evaluation of Holsteins in the Netherlands, EBVs for functional longevity were expressed as a relative breeding value with a mean of 100 and a genetic standard deviation of 4.5. Owing to trait definition and expression of the breeding value for longevity, the Dutch Cattle Improvement Organisation decided to exclude milk production as an effect from the model of their genetic evaluation from January 2008 onwards. The derived breeding value for productive longevity (true longevity) was expressed in days. The argument for changing from a relative to an absolute expression of the EBV for longevity was that an EBV in days clearly shows the effect of a bull on the longevity of his daughters (Van der Linde et al., 2007). 
The distribution of reliabilities among the proven sires is somewhat skewed (Figure 2). The mean reliability was $33.43 \%$ with a range of $0.82 \%$ to $95.66 \%$. These low reliabilities could be owing to an insufficient number of daughters for a more accurate proof because of the low heritability of the trait. The Canadian criterion for an official bull proof is $65 \%$ and 55\% reliability for production and type traits, respectively. Bull proof for herd life is published only when the criteria for type are met.

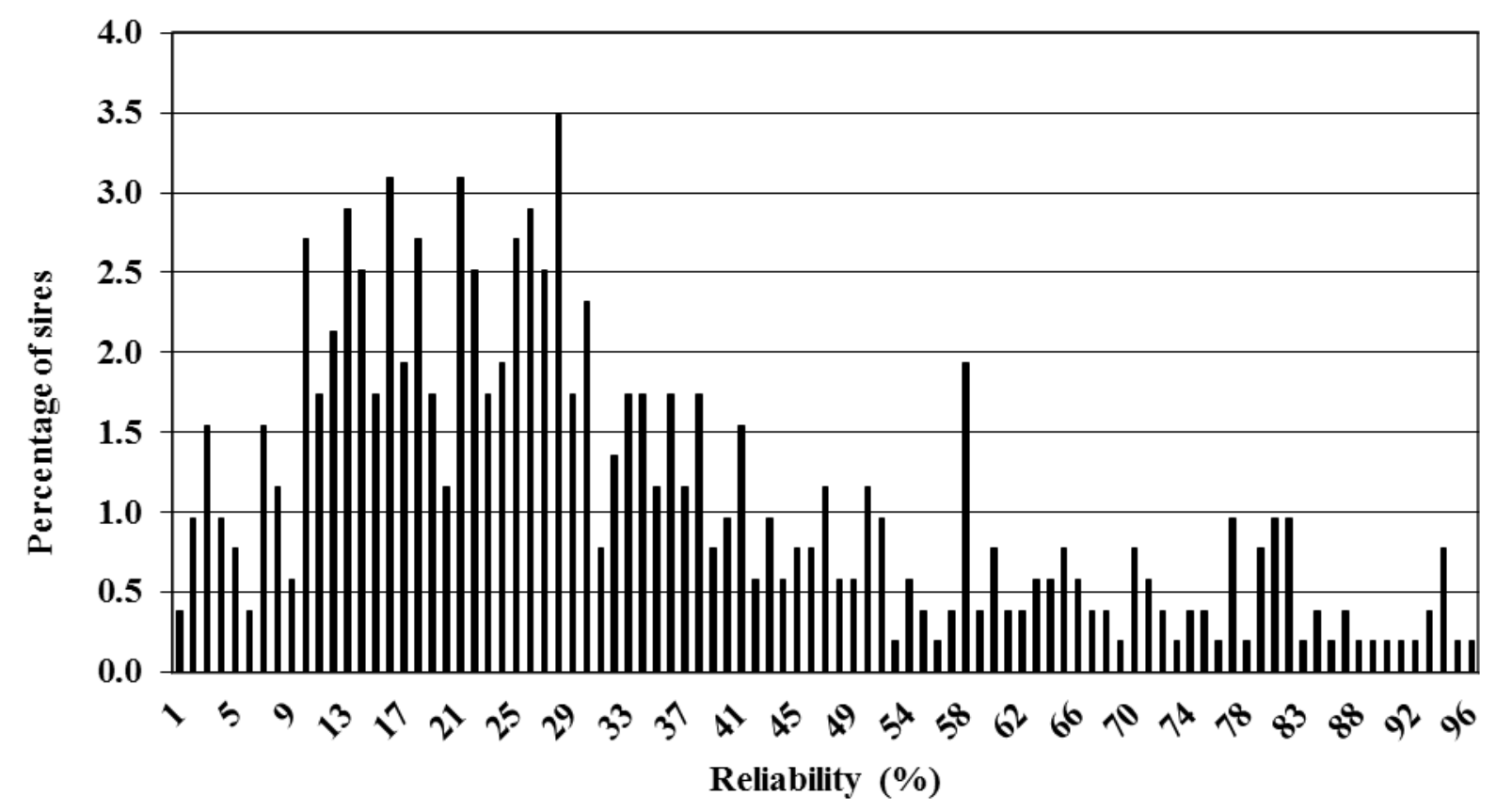

Figure 2 Distribution of reliabilities for all proven sires $(\mathrm{N}=559)$.

Figure 3 shows the genetic trend for longevity for proven bulls for the period 1985 to 2002 . The rate of genetic progress per year was statistically non-significant $(b=0.03 \pm 0.05$ per year). Similarly, Jairath et al . (1998) reported a slight positive trend for herd life when the means of expected transmitting ability (ETA) were plotted by year of birth.

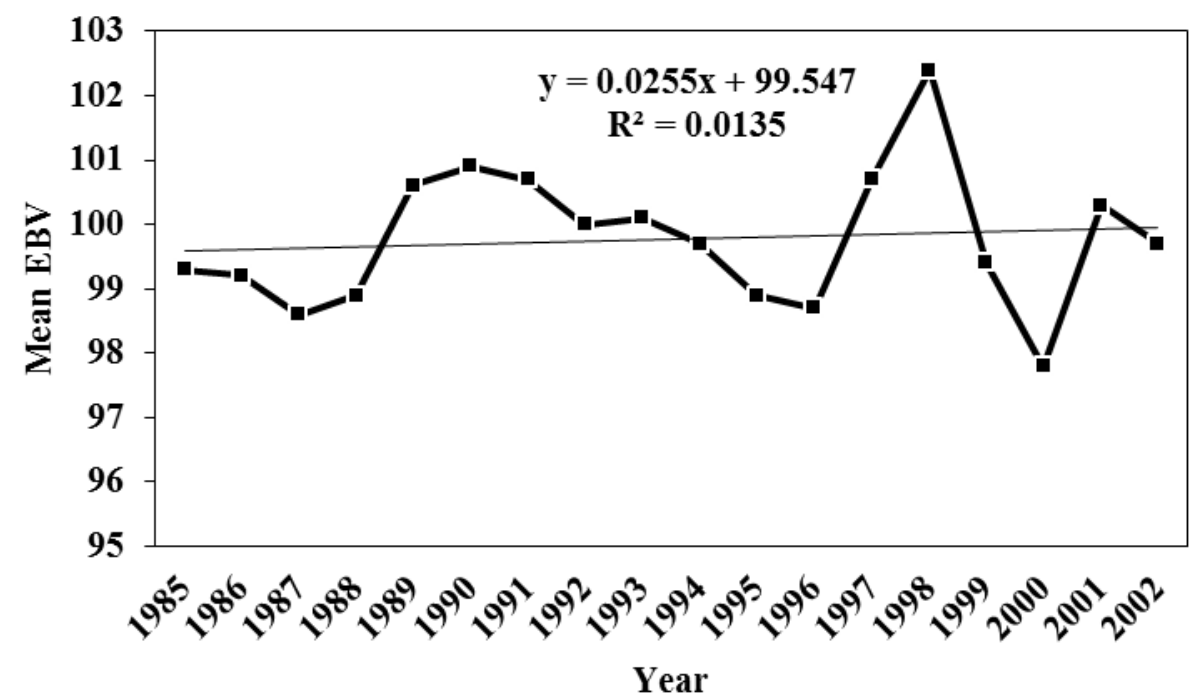

Figure 3 Genetic trend for longevity for proven sires $(n=433)$. 
In this study, cows were included in the analyses when they have initiated a first lactation. Survival could only be defined if there was a subsequent calving or the number of days between current calving date and data extraction date exceeded 581, similar to the procedure followed by Boettcher et al. (1999b) and Olori et al. (2002). This delay means that young bulls cannot be evaluated early for longevity, thus ruling out early selection decisions. A further delay is owing to the time it takes to have sufficient daughters for reliable proof because of the low heritability of the trait (Olori et al., 2002).

As reported by Boettcher et al. (1999b) on Canadian Holsteins, registered South African Jerseys are classified for conformation during their first lactations, and functional herd life includes the first three lactations. Therefore most bulls, particularly recent progeny test bulls, will have more daughter information for linear-type traits than for functional herd life. Thus the reliability of the proofs could be enhanced by including linear-type traits in the model for evaluation of longevity.

\section{Conclusion}

Correlated genetic response on longevity from direct selection on production was estimated in the current study. The results indicate that direct selection for production in the South African Jersey breed did not result in undesirable genetic response in longevity. In addition, the results from the current study indicate that direct selection for longevity in the South African Jersey breed is feasible. However, while direct selection for longevity could lead to genetic progress, this genetic response could be relatively slow owing to the low heritability and long generation interval.

\section{Acknowledgments}

This study formed part of the first author's doctorate thesis, which benefited from funding from the South African National Research Foundation.

\section{References}

Boettcher, P.J., Jairath, L.K. \& Dekkers, J.C.M., 1999a. Comparison of methods for genetic evaluation of sires for survival of their daughters in the first three lactations. J. Dairy Sci. 82, 1034-1044.

Boettcher, P.J., Jairath, L.K. \& Dekkers, J.C.M., 1999b. Genetic evaluation of herd life in Canada: Current status and future outlook. International workshop on EU concerted action Genetic Improvement of Functional traits in cattle (GIFT); Longevity Jouy-En-Josas, France May, 1999. Bulletin No. 21, 23-30.

Caraviello, D.Z., Weigel, K.L. \& Gianola, D., 2004. Prediction of longevity breeding values for US Holstein sires using survival analysis methodology. J. Dairy Sci. 87, 3518-3525.

Dekkers, J.C.M., Jairath, L.K. \& Lawrence, B.H., 1994. Relationships between sire genetic evaluations for conformation and functional herd life of daughters. J. Dairy Sci. 77, 844-854.

Ducrocq, V. \& Sölkner, J., 1998. "The Survival Kit'- V3.0, a package for large analyses of survival data. In: $6^{\text {th }}$ World Cong. Genet. Appl. Livest. Prod. 27, 447-448. Anim. Genetics and Breeding Unit, Univ. New England, Armidale, Australia.

Ducrocq, V., Quaas, R.L., Pollak, E.J. \& Casella, G., 1988. Length of productive life of dairy cows. I. Justification of a Weibull model. J. Dairy Sci. 71, 3061-3070.

Du Toit, J., Van Wyk, J.B. \& Maiwashe, A., 2009. Genetic parameter estimates for functional herd life for the South African Jersey breed using a multiple trait linear model. S. Afr. J. Anim. Sci. 39, 40-44.

Fikse, W.F. \& Banos, G., 2000. Weighting factors of sire daughter information in international genetic evaluations. J. Dairy Sci. 84, 1759-1767.

Forabosco, F., Jakobsen, J.H. \& Fikse, W.F., 2008. International genetic evaluation for direct longevity in dairy bulls. J. Dairy Sci. 92, 2338-2347.

Groeneveld, E., 1994. VCE - a multivariate multimodel REML (Co)variance component estimation package. Proc. $5^{\text {th }}$ Wrld Congr. Genet. Appl. Livest. Prod. 22: 47-48, Guelph, Canada.

Holtsmark, M., Heringstad, B. \& Odegard, J., 2009. Predictive abilities of different statistical models for analysis of survival data in dairy cattle. J. Dairy Sci. 92, 5730-5738.

Jairath, L.K. \& Dekkers, J.C.M., 1995. Operational model for genetic evaluation of functional herd life of Canadian Holsteins. J. Dairy Sci. 78 (Suppl. 1), 156. (Abstract). 
Jairath, L.K., Dekkers, J.C.M., Schaeffer, R.L., Liu, Z., Burnside, E.B. \& Kolstad, B., 1998. Genetic evaluation for herd life in Canada. J. Dairy Sci. 81, 550-562.

Liu, Z., Reinhardt, F., Bünger, A. \& Reents, R., 2004. Derivation and calculation of approximate reliabilities and daughter yield-deviations of a random regression test-day model for genetic evaluation of dairy cattle. J. Dairy Sci. 87, 1896-1907.

Madgwick, P.A. \& Goddard, M.E., 1989. Genetic and phenotypic parameters of longevity in Australian dairy cattle. J. Dairy Sci. 72, 2624-2632.

Miglior, F., 2005. Overview of different breeding objectives in various countries. Proc. $11^{\text {th }}$ WHFF Meeting Session 4, 7-11. Guelph, Ontario Canada.

Miglior, F., Muir, B.L. \& Van Doormaal, B.J., 2005. Selection indices in Holstein cattle of various countries. J. Dairy Sci. 88, 1255-1263.

Mostert, B.E., Groeneveld, E. \& Kanfer, F.H.J., 2004. Test day models for production traits in dairy cattle. S. Afr. J. Anim. Sci. 34, 35-37.

Olori, V.E., Meuwissen, T.H.E. \& Veerkamp, R.F., 2002. Calving interval and survival breeding values as measure of cow fertility in a pasture-based production system with seasonal calving. J. Dairy Sci. 85, 689-696.

Searle, S.R., Casella, G. \& McCulloch, C.E., 1992. Variance Components. John Wiley \& Sons, Inc., New York, N.Y., USA.

Settar, P. \& Weller, J.I., 1999. Genetic analysis of cow survival in the Israeli dair cattle population. J. Dairy Sci. 82, 2170-2177.

Sewalem, A., Miglior, F., Kistemaker, G.J., Sullivan, P. \& Van Doormaal, B.J., 2008. Relationship between reproduction traits and functional longevity in Canadian dairy cattle. J. Dairy Sci. 91, 1660-1668.

Short, T.H. \& Lawlor, T.J., 1992. Genetic parameters of conformation traits, milk yield and herd life in Holsteins. J. Dairy Sci. 75, 1987-1998.

Sölkner, J. \& Ducrocq, V., 1999. The survival kit: A tool for analysis of survival data. Interbull Bull. 21, 73-81.

Tsuruta, S., Misztal, I. \& Lawlor, T.J., 2005. Changing definition of productive life in US Holsteins: Effect on genetic correlations. J. Dairy Sci. 88, 1156-1165.

Van der Linde, C., Harbers, A.G.F. \& De Jong, G., 2007. From functional to productive longevity in the Netherlands. Interbull Bull. 37, 203-207.

Van Doormaal, B.J., 2010. A new look at herd life. Canadian Dairy Network. www.cdn.ca.

VanRaden, P.M. \& Wiggans, G.R., 1995. Productive life evaluations: calculation, accuracy, and economic value. J. Dairy Sci. 78, 631-638.

Veerkamp, R.F., Brotherstone, S., Engel, B. \& Meuwissen., T.H.E., 2001. Analysis of censored data using random regression models. Anim. Sci. 72, 1-10.

Visscher, P.M. \& Goddard, M.E., 1995. Genetic parameters for milk yield, survival, workability and type traits for Australian dairy cattle. J. Dairy Sci. 78, 205-220.

Vollema, ANT R. \& Groen, AB F., 1996. Genetic parameters of longevity traits of an upgrading population of dairy cattle. J. Dairy Sci. 79, 2261-2267.

Vukasinovic, N., Moll, J. \& Casanova, L., 2001. Implementation of a routine genetic evaluation for longevity based on survival analysis techniques in dairy cattle populations in Switzerland. J. Dairy Sci. 84, 2073-2080. 